\title{
Performance of WPA Conductivity Sensor during Two-Phase Fluid Flow in Microgravity
}

\author{
Layne Carter \\ NASA Marshall Space Flight Center \\ Edward W. O'Connor and Doug Snowdon \\ Hamilton Sundstrand Space Systems International, Inc.
}

Copyright $\odot 2003$ Society of Automotive Engineers, Inc.

\begin{abstract}
The Conductivity Sensor designed for use in the Node 3 Water Processor Assembly (WPA) was based on the existing Space Shuttle application for the fuel cell water system. However, engineering analysis has determined that this sensor design is potentially sensitive to twophase fluid flow (gas/liquid) in microgravity. The source for this sensitivity is the fact that gas bubbles will become lodged between the sensor probe and the wall of the housing without the aid of buoyancy in 1-g. Once gas becomes lodged in the housing, the measured conductivity will be offset based on the volume of occluded gas. A development conductivity sensor was flown on the NASA Microgravity Plan to measure the offset, which was determined to range between 0 and $50 \%$. Based on these findings, a development program was initiated at the sensor's manufacturer to develop a sensor design fully compatible with two-phase fluid flow in microgravity.
\end{abstract}

\section{INTRODUCTION}

The International Space Station (ISS) Node 3 Water Processor Assembly (WPA) produces potable water from waste waters generated on ISS. The WPA utilizes a series of treatment processes including filtration, ion exchange, adsorption, and catalytic oxidation (see Figure 1). Conductivity instrumentation is used to monitor the performance of the catalytic oxidation process (Reactor Health Sensor) and the ion exchange bed.

The WPA conductivity sensor design was based on a sensor used in the Space Shuttle fuel cell system. In this application, the fluid passing through the sensor is a two-phase mixture of water and gas at similar velocities to those seen in the WPA, though the gas content in the fuel cell application is higher. Due to the similarity of conditions and its successful zero-g operation, the Shuttle design was selected for use in the WPA. The only differences in geometry are that the fuel cell sensor necks down at the outlet to a small diameter fitting whereas the WPA sensor necks down in the manifold in which it is installed (see Figure 2). This difference would not affect two-phase operation. The flight qualified Shuttle design was therefore baselined for WPA with the expectation that two-phase flow would cause an offset in the conductivity reading, but that it would be temporary and insignificant. Any temporary offset would be easily filtered by software.

Free gaseous oxygen is fed to the WPA catalytic reactor to support the oxidation of organic contaminants. The gas/liquid separator subsequently removes excess free gas from the process stream. Performance testing of the WPA gas/liquid separator has shown that the separator will periodically release free gas to the downstream section during transient startups and at the end of the separator's useful life. This periodic release of free gas was not expected to be a design issue based on the understood ability of the downstream conductivity sensors to accommodate free gas. However, while conducting chemical development tests on the Reactor Health Sensor, a sustained offset was noted in conductivity as measured by the flight sensor. The offset disappeared when the sensor was oriented vertically, and was therefore attributed to gas inclusion while oriented horizontally. Since the offset was inconsistent with flight experience, an analysis was completed of the conductivity sensor housing design to evaluate its microgravity sensitivities to two-phase fluid flow. This analysis concluded that the housing design would occlude gas in the liquid flow path because there were flow regions in the housing with insufficient velocity to generate the required pressure drop to remove the free gas. Since the conductivity of the gas is less than water, the effect of gas occlusion is a reduced conductivity value (relative to the actual conductivity of the water). Based on these conclusions, engineers at HSSSI and MSFC evaluated the sensor design during ground testing and on the NASA microgravity plane to quantify the effect of two-phase flow on the sensor performance. The data was subsequently used to determine if the sensor function could still be met on-orbit with the predicted offset. 


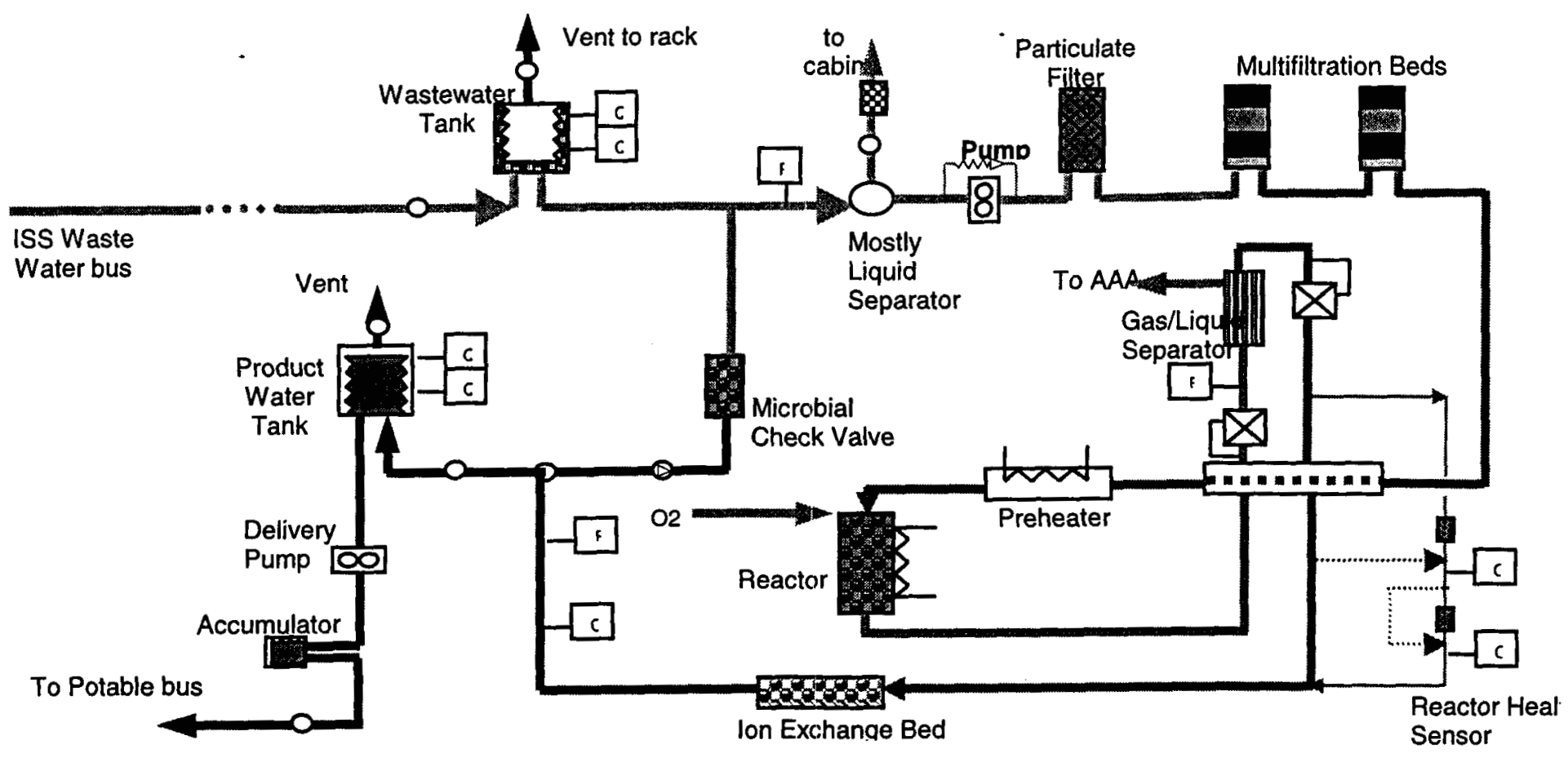

Figure 1. Water Processor Schematic

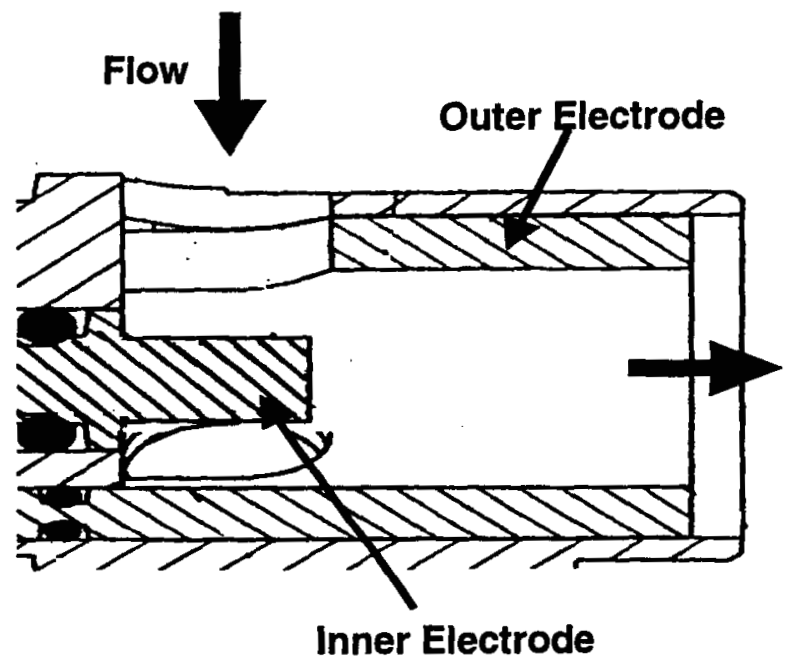

Figure 2. WPA Conductivity Sensor Housing

\section{GROUND TEST DESCRIPTION}

In testing conducted at the supplier, the two sensor concepts (product water sensor maximum range of 50 $\mu \mathrm{S} / \mathrm{cm}$ and Reactor Health Sensor range of $500 \mu \mathrm{S} / \mathrm{cm}$ ) were tested concurrently at the system design water flow rate of $120 \mathrm{ml} / \mathrm{min}$. Initially, gas was introduced in small measured bubbles one at time. After that series of tests, a steady stream of bubbles (1\% gas by volume) was introduced. In the initial tests with individual bubbles, there was no gas discharge from the sensors until $1.8 \mathrm{cc}$ of gas had accumulated in each sensor. The bubbles accumulated and produced a significant offset in reading as shown in Figure 3.

The steady stream of bubbles exhibited a similar offset due to accumulated gas, except that as each bubble passed through the sensor a momentary transient response overlaid the offset. Even with small bubbles, all gas would accumulate in the sensor until the same offset was reached. Based on the ground testing, the design engineers concluded that gas will occlude in the sensor housing (in the horizontal orientation) resulting in a $1-\mathrm{g}$ sensor offset of $40 \%$ to $60 \%$.

\section{MICROGRAVITY TEST DESCRIPTION}

In the next phase of this investigation, MSFC and HS initiated an effort with Texas A\&M University to conduct an experiment with the conductivity sensor on the NASA micro-gravity plane. Because of the different conductivity ranges required in the Reactor Health Sensor $(500$ $\mu \mathrm{S} / \mathrm{cm}$ maximum) and the lon Exchange Bed effluent (50 $\mu \mathrm{S} / \mathrm{cm}$ maximum), these two sensors have probes of varying length (0.237 and 0.467 inches, respectively). Both sensor concepts were tested to determine if the varying probe length resulted in different offsets in microgravity. The primary objective of the KC-135 test was to measure the offset of the conductivity sensor when exposed to two-phase fluid flow in microgravity. 


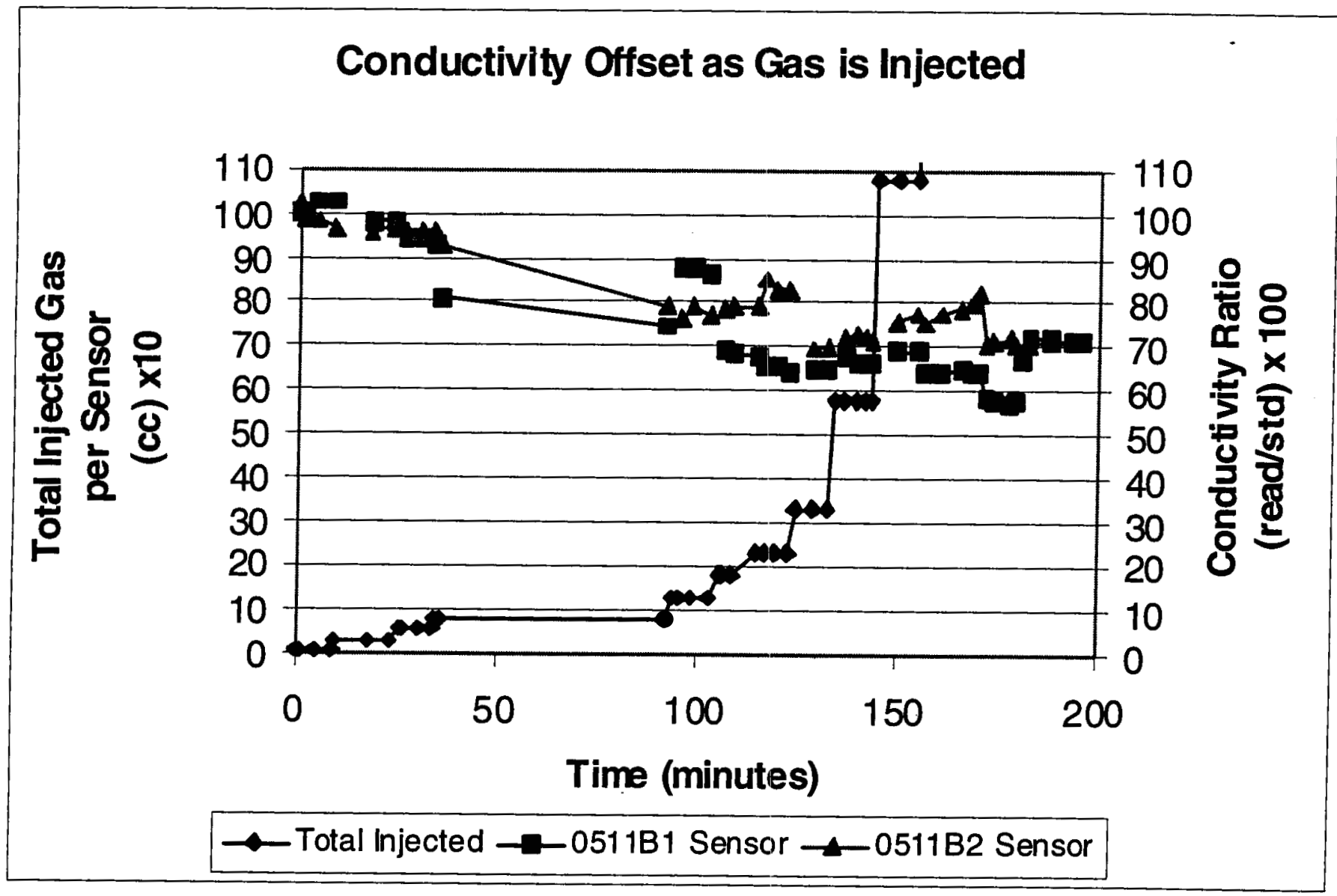

Figure 3. Summary of Ground Test Data 


\section{MICROGRAVITY TEST PLAN}

During the experiment, each sensor was tested under various conditions to identify the possible ranges for the offset. These conditions included operating the sensor in each orientation (horizontal, vertical with outlet up, and vertical with outlet down) and under various gas influent conditions (individual bubbles at varying frequencies and Taylor bubbles of varying sizes). The housing orientation dictated the distribution of gas during the 2-g period and thereby the gas distribution when the microgravity segment was initiated. The various gas influent conditions represented the environment expected in the flight hardware. These various conditions were evaluated during the first two days of the KC-135 test to identify the conditions under which viable data could be generated. This testing was performed with the product water sensor (range of $50 \mu \mathrm{S} / \mathrm{cm}$ ). Table 1 summarizes the testing planned for the first two days and the general observations. As a result of these tests, the test plan for days 3 and 4 was established. The Reactor Health Conductivity sensor was evaluated on Day 3 and the product water conductivity sensor on Day 4. Two techniques yielded the most viable data for assessing the sensor offset. The first approach was the simultaneous introduction of liquid and gas (at a combined flow rate of $120 \mathrm{ml} / \mathrm{min}$ ). Different combinations of flow rates were used depending on the sensor orientation. This approach resulted in a steady flow of discrete bubbles to the sensor, resulting in the periodic occlusion and release of gas in the sensor housing. The second technique was to introduce a slug of gas once the microgravity period was established. Testing on Days 1 and 2 showed that a slug of gas typically cleared the housing of all gas and resulted in an offset of near zero. Table 2 summarizes the various test conditions evaluated on test days 3 and 4 and the range of conductivity values observed during each parabola.

A schematic of the test rig is provided in Figure 4. In the primary flow loop, the gas/liquid flow stream is processed through a vortex separator to deliver a liquid-only feed source for the experiment. A liquid flow rate of approximately $120 \mathrm{ml} / \mathrm{min}$ (nominal flow rate for the Water Processor) was maintained in the experiment loop (including the conductivity sensor) using a metering valve. Gas was periodically injected into the experiment loop as a Taylor bubble or as discrete bubbles to evaluate the response of the conductivity sensor to the full range of potential gas feed conditions. The conductivity sensor and required test equipment were located on a rotating platform to enable the sensor to be assessed in varying orientations. Though these orientations were not affected by microgravity, they did dictate gas distribution during the 2-g periods, thereby dictating the initial condition in the housing when the microgravity period began. Clear teflon tubing was installed immediately before and after the sensor to observe the gas condition going into and out of the housing. The effluent of the experiment loop was returned to the vortex for gas removal.

Table 1. Summary of Test Days 1 and 2

\begin{tabular}{|c|c|c|}
\hline Parabola & Orientation & Comments \\
\hline \multicolumn{3}{|l|}{ Day 1} \\
\hline 1 to 10 & Horizontal & $\begin{array}{l}\text { Establishing gas/liquid flow in test loop, gas injected in } \sim 0.3 \text { to } 0.5 \mathrm{cc} \text { slugs for } \\
\text { parabolas } 6-10 \text {, but little gas in effluent and no significant offset observed. }\end{array}$ \\
\hline 11 to 20 & Horizontal & $\begin{array}{l}\text { 1-2 cc injected as individual bubbles per parabola, typically observed } 0.5^{\prime \prime} \text { to } 1 " \\
\text { Taylor bubbles and periodic individual bubbles in effluent; sensor offset of } 0-50 \% \text {. }\end{array}$ \\
\hline 21 to 30 & Vertical Down & $\begin{array}{l}-2 \text { cc injected as individual bubbles per parabola, typically observed } 0.2^{\prime \prime} \text { to } 0.5^{\prime \prime} \\
\text { Taylor bubles and periodic individual bubbles in effluent; sensor offset of } 0-45 \% \text {. }\end{array}$ \\
\hline 31 to 40 & Vertical Up & $\begin{array}{l}\text { Inject } 4 \mathrm{cc} \text { gas during parabola, } 2-\mathrm{G} \text { flow to reestablish housing as water solid, } \\
\text { typically observed } 0.2^{\prime \prime} \text { to } 0.5^{\prime \prime} \text { Taylor bubbles and periodic isolated bubbles in } \\
\text { effluent toward end of parabola; sensor offset of } 0-50 \%\end{array}$ \\
\hline \multicolumn{3}{|l|}{ Day 2} \\
\hline 1 to 10 & Vertical Down & $\begin{array}{l}\text { Established housing as gas solid in } 2 G \text {, then no gas injection during } \mu-G \text { to assess } \\
\text { quantity of gas occlusion when liquid flow is initiated in } \mu-G \text {, conductivity reading } \\
\text { returned to } 0 \% \text { offset when liquid flow initiated in } \mu-G \text {. }\end{array}$ \\
\hline 11 to 15 & Vertical Down & $\begin{array}{l}\text { Inject } 3 \mathrm{cc} \text { during } 2-\mathrm{g} \text { (no liquid flow) that is fed to the sensor (with liquid flow) } \\
\text { when } \mu-g \text { was initiated, resulted in sensor offset of } 0-25 \%\end{array}$ \\
\hline 16 to 20 & Vertical Down & Inject $1 \mathrm{cc}$ during $\mu-\mathrm{g}$ with liquid flow, resulted in sensor offset of $0-30 \%$ \\
\hline 21 to 25 & Horizontal & Inject $1 \mathrm{cc}$ during $\mu-\mathrm{g}$ with liquid flow, resulted in sensor offset of $0-35 \%$ \\
\hline 26 to 30 & Horizontal & $\begin{array}{l}\text { Inject } 3 \mathrm{cc} \text { during } 2-\mathrm{g} \text { (no liquid flow) that is fed to the sensor (with liquid flow) } \\
\text { when } \mu-g \text { was initiated, resulted in sensor offset of } 0-40 \%\end{array}$ \\
\hline 31 to 35 & Vertical Up & $\begin{array}{l}\text { Inject } 5 \mathrm{cc} \text { gas during parabola, } 2-\mathrm{G} \text { flow to reestablish housing as water solid, } \\
\text { resulted in sensor offset of } 0-50 \%\end{array}$ \\
\hline 36 to 40 & Veritical Up & Inject gas at $10 \mathrm{cc} / \mathrm{min}$ during $\mu-\mathrm{g}$, resulted in sensor offset of $10-35 \%$ \\
\hline
\end{tabular}


Table 2. Summary of Conditions and Results for Test Days 3 and 4

\begin{tabular}{|c|c|c|c|c|c|c|c|c|c|}
\hline Orientation & $\begin{array}{c}\text { Liquid } \\
\text { Flow } \\
\text { (ml/min) } \\
\end{array}$ & Gas Flow & $\begin{array}{c}\text { Min Stable } \\
\text { Cond } \\
\text { (umhos/cm) }\end{array}$ & $\begin{array}{l}\text { Measured } \\
\text { Offset (\%) }\end{array}$ & Orientation & $\begin{array}{c}\text { Liquid } \\
\text { Flow } \\
\text { (ml/min) }\end{array}$ & Gas Flow & $\begin{array}{c}\text { Min Stable } \\
\text { Cond } \\
\text { (umhos/cm) }\end{array}$ & $\begin{array}{l}\text { Measured } \\
\text { Offset (\%) }\end{array}$ \\
\hline Day 3 & & & & & Day 4 & & & & \\
\hline Horizontal & 115 & $5 \mathrm{ml} / \mathrm{min}$ & * & & Vertical Up & 120 & 0 & 51 & 7.3 \\
\hline Horizontal & 115 & $5 \mathrm{ml} / \mathrm{min}$ & 26 & 51.9 & Vertical Up & 115 & $5 \mathrm{ml} / \mathrm{min}$ & 40 & 27.3 \\
\hline Horizontal & 115 & $5 \mathrm{ml} / \mathrm{min}$ & 32 & 40.7 & Vertical Up & 115 & $5 \mathrm{ml} / \mathrm{min}$ & 39 & 29.1 \\
\hline Horizontal & 115 & $5 \mathrm{ml} / \mathrm{min}$ & 27 & 50.0 & Vertical Up & 115 & $5 \mathrm{ml} / \mathrm{min}$ & * & \\
\hline Horizontal & 115 & $5 \mathrm{ml} / \mathrm{min}$ & 31 & 42.6 & Vertical Up & 117 & $3 \mathrm{ml} / \mathrm{min}$ & 40 & 27.3 \\
\hline Horizontal & 115 & $5 \mathrm{ml} / \mathrm{min}$ & 37 & 31.5 & Vertical Up & 117 & $3 \mathrm{ml} / \mathrm{min}$ & 46 & 16.4 \\
\hline Horizontal & 120 & 5 cc slug & 46 & 14.8 & Vertical Up & 117 & $3 \mathrm{ml} / \mathrm{min}$ & 42 & 23.6 \\
\hline Horizontal & 120 & $5 \mathrm{cc}$ slug & 51 & 5.6 & Vertical Up & 117 & $3 \mathrm{ml} / \mathrm{min}$ & 43 & 21.8 \\
\hline Horizontal & 120 & 5 cc slug & 51 & 5.6 & Horizontal & 115 & $5 \mathrm{ml} / \mathrm{min}$ & 39 & 29.1 \\
\hline Horizontal & 120 & 5 cc siug & 49 & 9.3 & Horizontal & 115 & $5 \mathrm{ml} / \mathrm{min}$ & 34 & 38.2 \\
\hline Vertical Up & 115 & $5 \mathrm{ml} / \mathrm{min}$ & 34 & 37.0 & Horizontal & 115 & $5 \mathrm{ml} / \mathrm{min}$ & * & \\
\hline Vertical Up & 115 & $5 \mathrm{ml} / \mathrm{min}$ & 38 & 29.6 & Horizontal & 115 & $5 \mathrm{ml} / \mathrm{min}$ & 36 & 34.5 \\
\hline Vertical Up & 115 & $5 \mathrm{ml} / \mathrm{min}$ & 34 & 37.0 & Horizontal & 115 & $5 \mathrm{ml} / \mathrm{min}$ & 30 & 45.5 \\
\hline Vertical Up & 115 & $5 \mathrm{ml} / \mathrm{min}$ & 34 & 37.0 & Horizontal & 117 & $3 \mathrm{ml} / \mathrm{min}$ & 35 & 36.4 \\
\hline Vertical Up & 115 & $5 \mathrm{ml} / \mathrm{min}$ & 30 & 44.4 & Horizontal & 117 & $3 \mathrm{ml} / \mathrm{min}$ & 37 & 32.7 \\
\hline Vertical Up & 115 & $5 \mathrm{ml} / \mathrm{min}$ & 34 & 37.0 & Horizontal & 117 & $3 \mathrm{ml} / \mathrm{min}$ & 39 & 29.1 \\
\hline Vertical Up & 120 & 5 cc slug & 51 & 5.6 & Horizontal & 117 & $3 \mathrm{ml} / \mathrm{min}$ & 37 & 32.7 \\
\hline Vertical Up & 120 & $5 \mathrm{cc}$ slug & 53 & 1.9 & Horizontal & 117 & $3 \mathrm{ml} / \mathrm{min}$ & 36 & 34.5 \\
\hline Vertical Up & 120 & 5 cc slug & 53 & 1.9 & Horizontal & 120 & 5 cc slug & 47 & 14.5 \\
\hline Nertical Up & 120 & $5 \mathrm{cc}$ slug & 48 & 11.1 & Horizontal & 120 & 5 cc slug & 44 & 20.0 \\
\hline Vertical Down & 115 & $5 \mathrm{ml} / \mathrm{min}$ & 30 & 44.4 & Vertical Down & 115 & $5 \mathrm{mi} / \mathrm{min}$ & 40 & 27.3 \\
\hline Vertical Down & 115 & $5 \mathrm{ml} / \mathrm{min}$ & * & & Vertical Down & 115 & $5 \mathrm{ml} / \mathrm{min}$ & 34 & 38.2 \\
\hline Vertical Down & 115 & $5 \mathrm{ml} / \mathrm{min}$ & 32 & 40.7 & Vertical Down & 115 & $5 \mathrm{ml} / \mathrm{min}$ & 34 & 38.2 \\
\hline Vertical Down & 115 & $5 \mathrm{ml} / \mathrm{min}$ & 30 & 44.4 & Vertical Down & 115 & $5 \mathrm{ml} / \mathrm{min}$ & 27 & 50.9 \\
\hline Nertical Down & 115 & $5 \mathrm{ml} / \mathrm{min}$ & 35 & 35.2 & Vertical Down & 115 & $5 \mathrm{ml} / \mathrm{min}$ & 31 & 43.6 \\
\hline Vertical Down & 115 & $5 \mathrm{ml} / \mathrm{min}$ & 32 & 40.7 & Vertical Down & 115 & $5 \mathrm{ml} / \mathrm{min}$ & 35 & 36.4 \\
\hline Vertical Down & 120 & 5 cc slug & 38 & 29.6 & Vertical Down & 117 & $4 \mathrm{ml} / \mathrm{min}$ & 37 & 32.7 \\
\hline Vertical Down & 120 & 5 cc slug & 26 & 51.9 & Vertical Down & 117 & $4 \mathrm{ml} / \mathrm{min}$ & 29 & 47.3 \\
\hline Vertical Down & 120 & $5 \mathrm{cc}$ slug & 37 & 31.5 & Vertical Down & 117 & $4 \mathrm{ml} / \mathrm{min}$ & 40 & 27.3 \\
\hline Nertical Down & 120 & $5 \mathrm{cc}$ slug & 48 & 11.1 & Vertical Down & 117 & $4 \mathrm{ml} / \mathrm{min}$ & 30 & 45.5 \\
\hline Vertical Down & 110 & $10 \mathrm{ml} / \mathrm{min}$ & 30 & 44.4 & Vertical Down & 117 & $4 \mathrm{ml} / \mathrm{min}$ & 31 & 43.6 \\
\hline Vertical Down & 110 & $10 \mathrm{ml} / \mathrm{min}$ & 31 & 42.6 & Vertical Down & 117 & $4 \mathrm{ml} / \mathrm{min}$ & 30 & 45.5 \\
\hline Vertical Down & 110 & $10 \mathrm{ml} / \mathrm{min}$ & 27 & 50.0 & Vertical Down & 110 & $10 \mathrm{ml} / \mathrm{min}$ & 29 & 47.3 \\
\hline Vertical Down & 110 & $10 \mathrm{ml} / \mathrm{min}$ & 29 & 46.3 & Vertical Down & 110 & $10 \mathrm{ml} / \mathrm{min}$ & 36 & 34.5 \\
\hline Vertical Down & 110 & $10 \mathrm{ml} / \mathrm{min}$ & 26 & 51.9 & Vertical Down & 110 & $10 \mathrm{ml} / \mathrm{min}$ & 33 & 40.0 \\
\hline Vertical Down & 117 & $3 \mathrm{ml} / \mathrm{min}$ & 32 & 40.7 & Vertical Down & 110 & $10 \mathrm{ml} / \mathrm{min}$ & 34 & 38.2 \\
\hline Nertical Down & 117 & $3 \mathrm{ml} / \mathrm{min}$ & 33 & 38.9 & Vertical Down & 110 & $10 \mathrm{ml} / \mathrm{min}$ & 39 & 29.1 \\
\hline Vertical Down & 117 & $3 \mathrm{ml} / \mathrm{min}$ & $\star *$ & & Vertical Down & 110 & $10 \mathrm{ml} / \mathrm{min}$ & 31 & 43.6 \\
\hline \multirow[t]{2}{*}{ Vertical Down } & 117 & $3 \mathrm{ml} / \mathrm{min}$ & 34 & 37.0 & Vertical Down & 120 & $5 \mathrm{cc}$ slug & 36 & 34.5 \\
\hline & & & & & Vertical Down & 120 & 5 cc slug & 47 & 14.5 \\
\hline
\end{tabular}




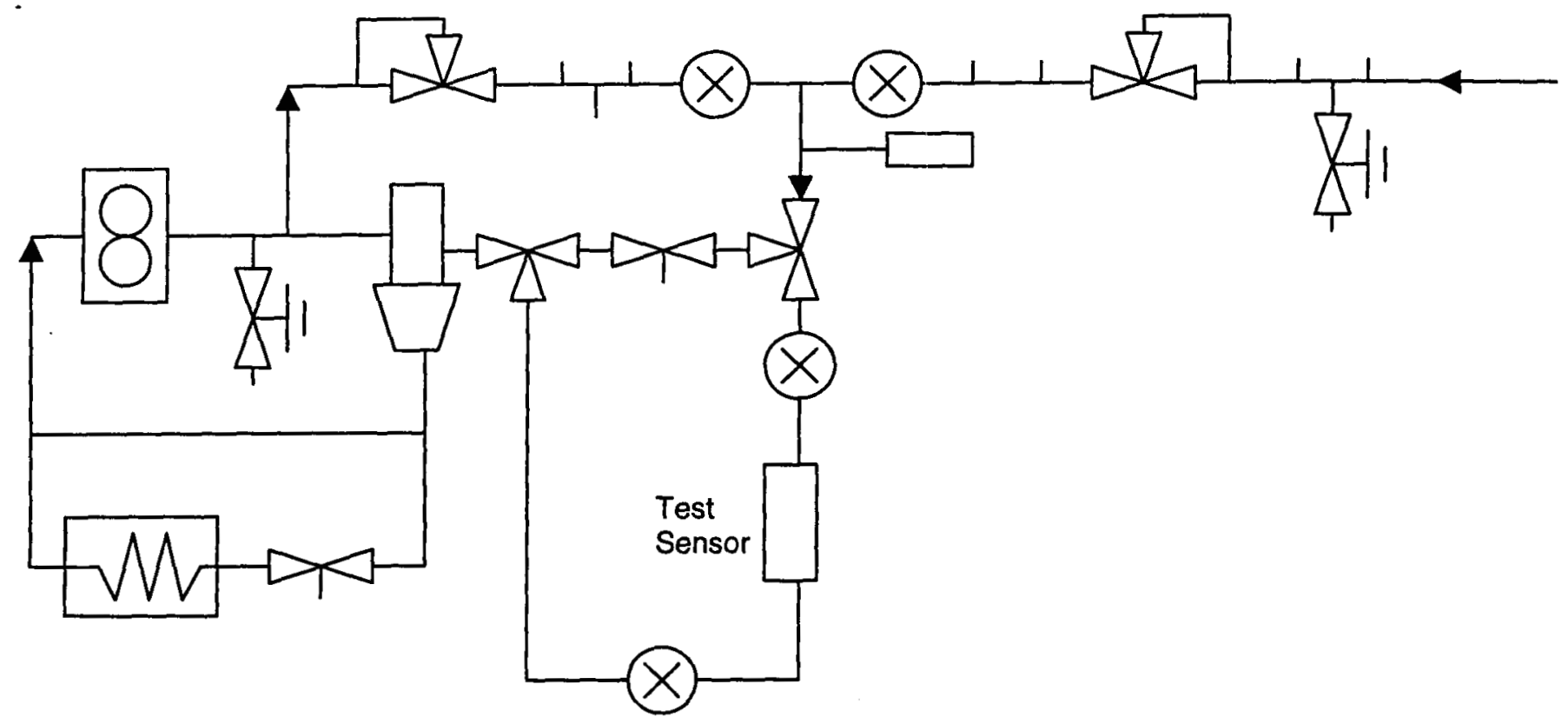

\section{MICROGRAVITY TEST RESULTS}

Each parabola from Test Days 3 and 4 was analyzed to identify the minimum stable conductivity during each parabola. A momentary downspike in the data indicated the passage of a gas bubble through the housing, but was not considered in the analysis because the level of gas occlusion in the housing could not be maintained. By conducting these series of parabolas, the sensor housing was exposed to a statistically valid range of influent liquid/gas conditions to identify the largest volume of gas that could credibly occlude in the housing (resulting in the maximum offset). A summary of this data is provided in Table 2.

The typical response of the sensor to the introduction of discrete gas bubbles is provided in Figures 5 and 6 . As gas is introduced to the housing, it occludes until additional gas flow reaches the housing. As the additional gas occludes in the housing, the increased pressure drop of the liquid (flowing around the occluded gas) tends to push a portion of the gas out of the housing. Though gas entered the housing as discrete bubbles, it typically exited as Taylor bubbles with periodic discrete bubbles trailing. The stable gas occlusion varied widely during the test because of the dynamics associated with the two-phase fluid flow, including the introduction of the different phases into the housing and the relative size of each gas bubble.

As mentioned previously, the introduction of a Taylor bubble to the sensor typically cleared all gas from the housing. Figure 7 shows a typical response on Test Day 4, Parabola 40. However, on several parabolas a portion of the bubble would remain in the housing, resulting in offsets as high as $52 \%$.

Over the course of the testing, it was also observed that relatively small, discrete bubbles would typically pass directly through the housing if there were no significant occlusion present. This result occurs because the discrete bubbles will typically remain in the liquid flow path unless they are captured by occluded gas already present in the housing. This fact may be further used by design engineers in the development of design modifications that would introduce gas to the sensor housing in a manner that would minimize occlusion. 
Figure 5. Day 4, Parabola 6

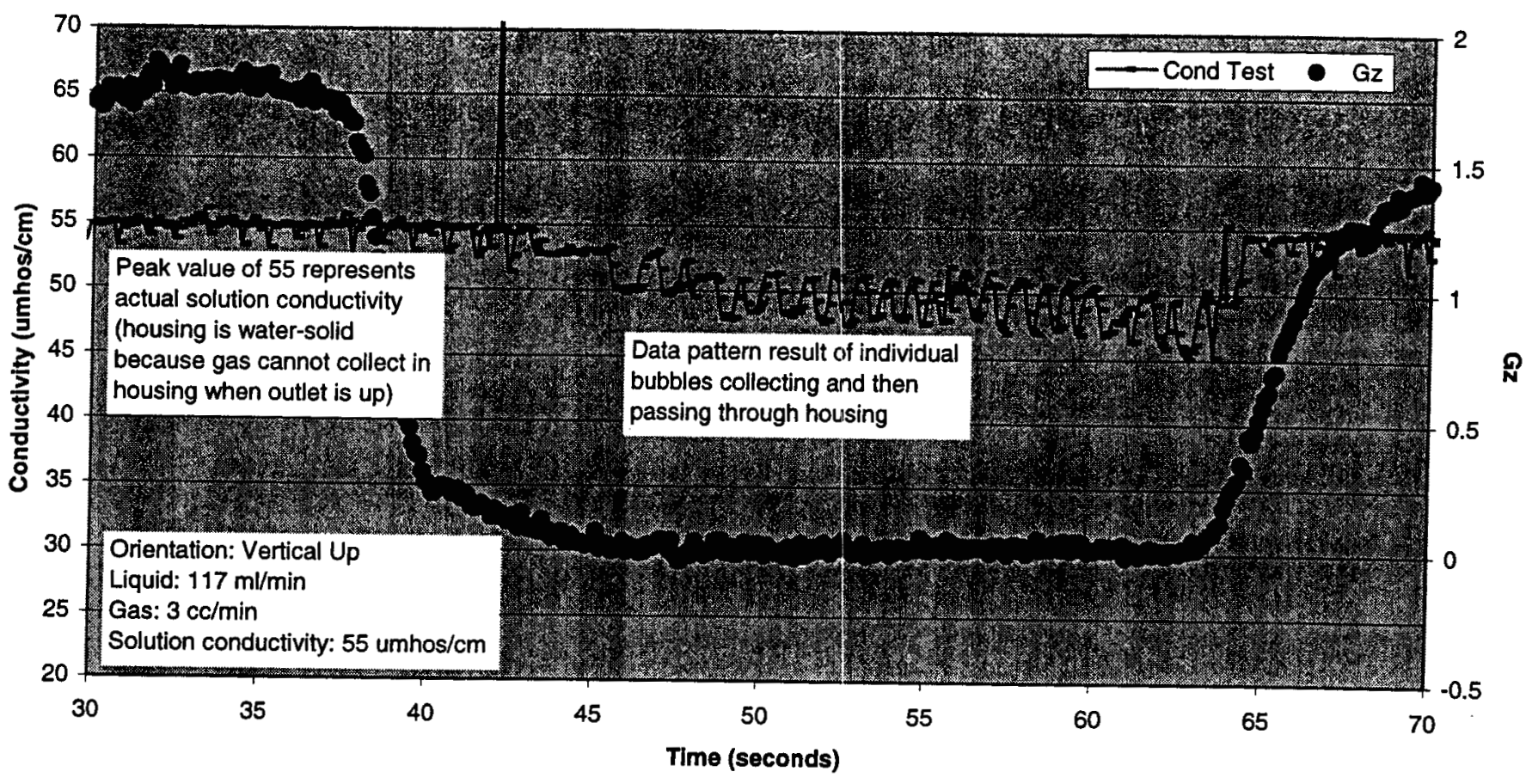

Figure 6. Day 4, Parabola 13

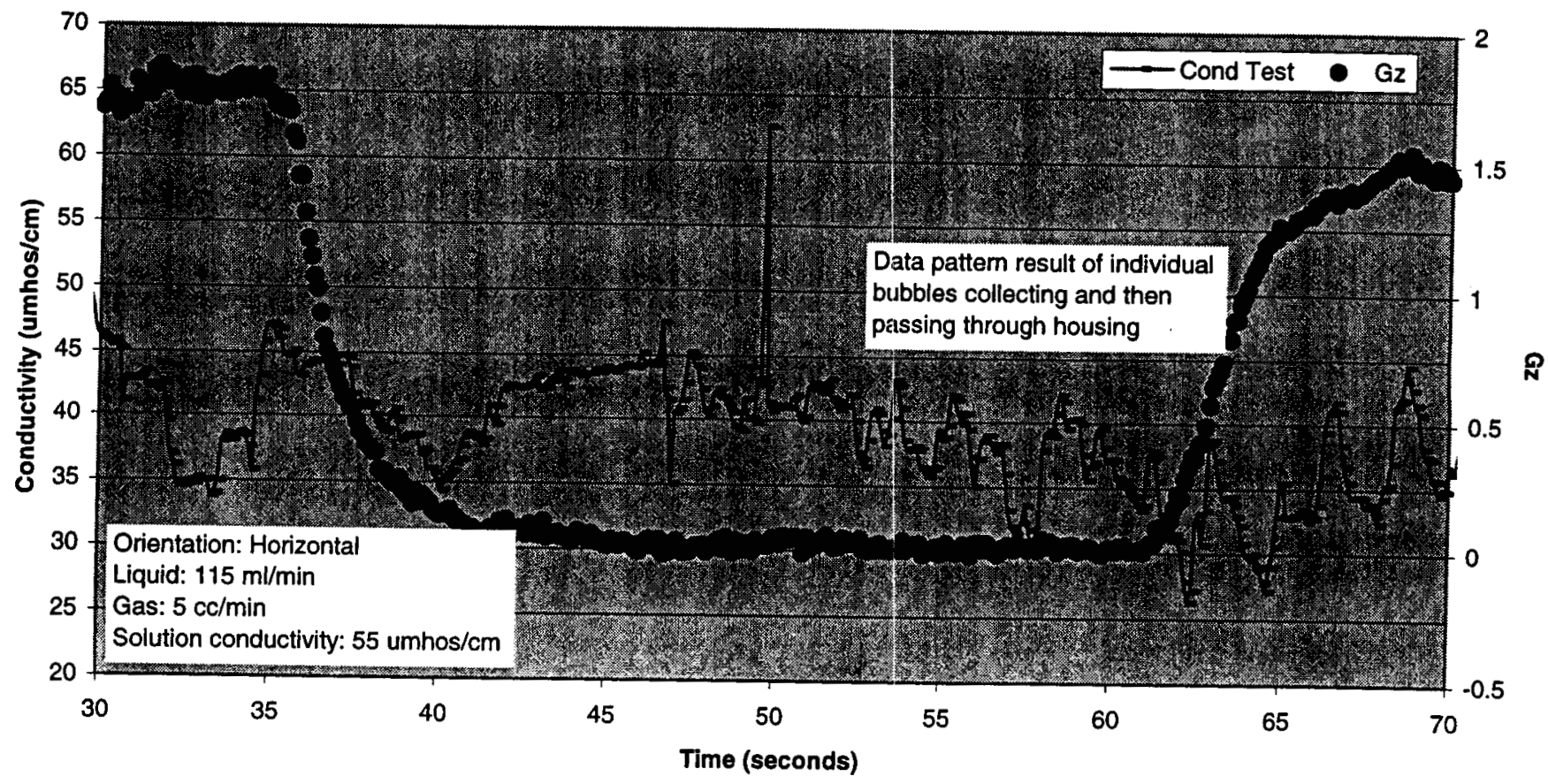


Figigurex. Doy \& Pawathoda4to

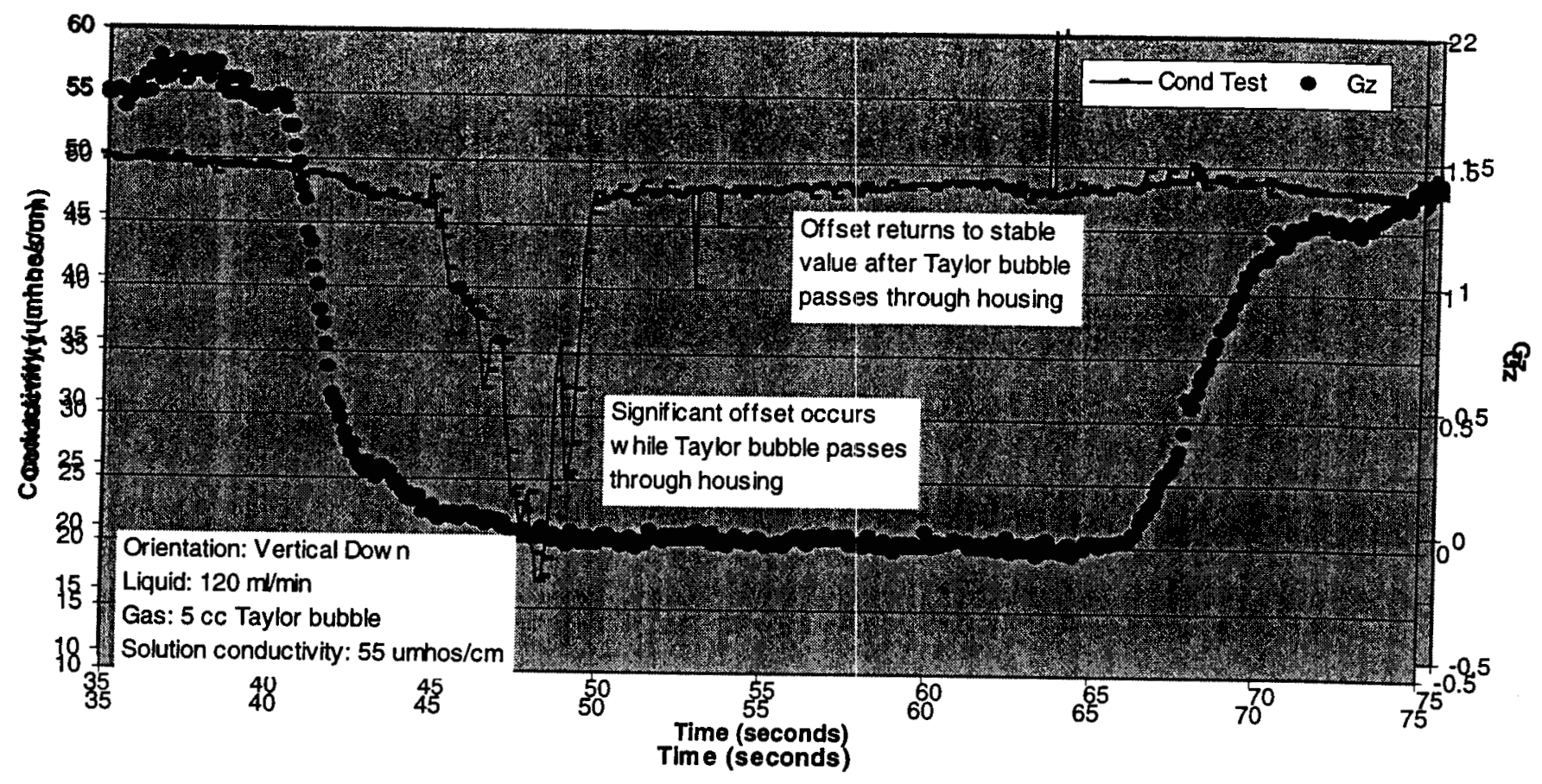




\section{MICROGRAVITY TEST CONCLUSIONS}

Based on the test results, the potential offset in each sensor has been defined as $0-50 \%$, meaning the sensor reading could be accurate (if no gas is present in the housing) or up to one-half of the actual conductivity of the water. The impact of this offset on the operation of the Reactor Health Sensor is unacceptable. The conductivity sensor used to monitor the performance of the catalytic reactor effectively correlates the reactor's influent organic content to an effluent conductivity (as the organic constituents are oxidized to inorganic compounds). As shown in Figure 8, the offset due to gas inclusion could allow twice the inlet organic load to the reactor before reaching the setpoint indicated the reactor capacity has been exceeded. The end result is the delivery of product water that would not meet the potable requirement for organic content.

\section{Conductivity Sensor/Reactor Interaction - 50\% Gas Offset}

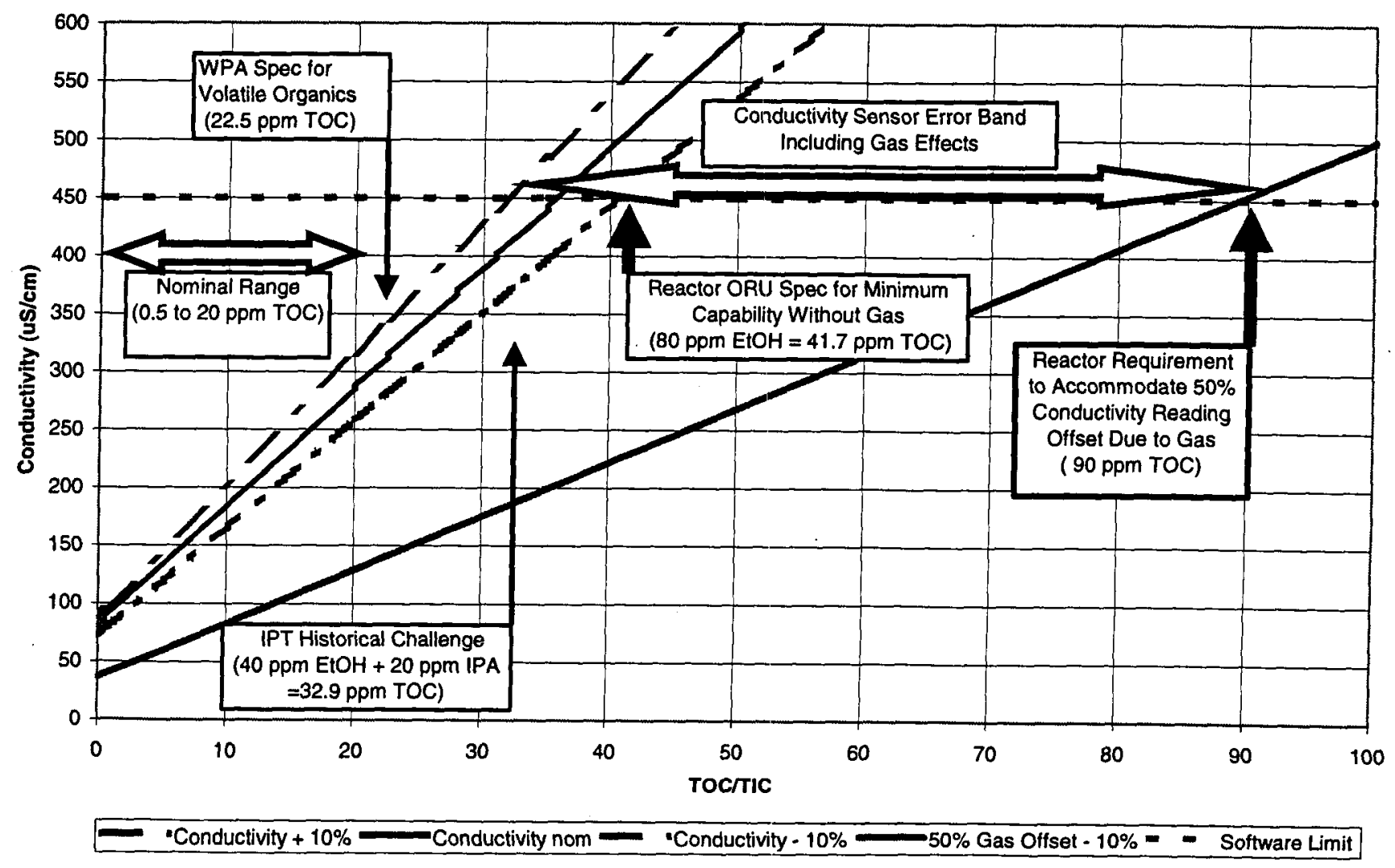


Assessment of the baseline design indicated two regions for gas entrapment: 1) the neckdown at the outlet which trapped gas and 2) the flow stagnation region at the base of the inner electrode which would not be penetrated by the low velocity inlet flow. Extensive two-phase testing at Hamilton Sundstrand has shown that gas will not be trapped in sections of tubing that are smooth, without discontinuities, constant diameter and are the narrowest tube section in the assembly. Hamilton Sundstrand originated a conductivity sensor concept that consists of immersed electrodes base on the lessons learned for managing two-phase flow. As seen in the Figure 9, the gas-tolerant conductivity sensor is essentially a smooth bore small diameter $(0.160$ " ID) tube of insulating material with electrodes imbedded on opposing faces of the tube ID. The complete flow path is straight, is a flowthru device, and is machined to make the bore smooth from inlet to outlet. The diameter of the flow path is smaller than the inlet or outlet tubing. An outer shell contains the electrodes and insulators and provides a leak and pressure barrier.

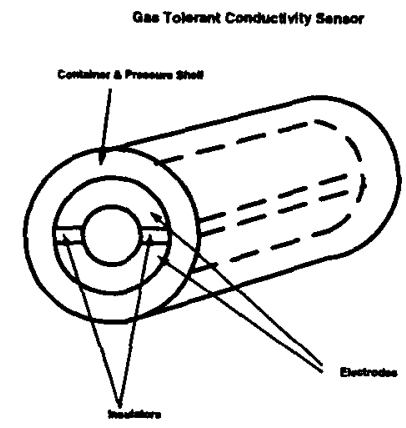

Figure 9. Concept for Modified Sensor Housing

Goodrich Sensor Systems developed a gas tolerant conductivity sensor based on the Hamilton Sundstrand concept and conducted two-phase testing on the device similar to the testing conducted on the initial sensor. In addition to the baseline $16 \mathrm{lb} / \mathrm{hr}(120 \mathrm{cc} / \mathrm{min})$ water flow tests, additional exploratory tests at lower flows were conducted. That testing demonstrated the ability to clear gas bubbles from the electrode area with extremely low water flow rates $(8 \mathrm{cc} / \mathrm{min})$ and velocities $(0.37 \mathrm{in} / \mathrm{sec})$. Under all WPA operating conditions in which gas is contained in the water, the gas-tolerant conductivity sensor exhibits a 10:1 water flow/velocity margin on clearing gas.

Test procedures specified conducting two-phase flow tests in the horizontal (gravity minimized) attitude with the tube rotated to five different positions about its axis. This rotation would determine if material properties (in particular, surface tension) or internal positioning would affect performance. Clear tubing on the inlet and outlet of the sensor allowed observation of the bubbles. Sensor voltage readouts determined conditions within the sensor. The sensor tested is the $500 \mathrm{uS} / \mathrm{cm}$ model with inlet conductivity of approximately $250 \mathrm{uS} / \mathrm{cm}$ and an output voltage of 4.8 volts. Smallest bubbles injected were approximately $0.1 \mathrm{cc}$. Results of that testing are as follows:

1) At $120 \mathrm{cc} / \mathrm{min}$ water flow $(5.5 \mathrm{in} / \mathrm{sec}$ water velocity in the 0.168 " max ID tubing bore), all bubbles (single or in a train) would clear the electrodes immediately in all rotational orientations. Occasionally, some would hang up at the inlet for a few seconds, but not at the electrodes.

2) At $90 \mathrm{cc} / \mathrm{min}$ water flow $(4.1 \mathrm{in} / \mathrm{sec})$, the results were the same as at $120 \mathrm{cc} / \mathrm{min}$.

3) At $4 \mathrm{cc} / \mathrm{min}$ water flow ( $0.18 \mathrm{in} / \mathrm{sec}$ ) and oriented with the electrodes on opposing sides, bubbles generally cleared the electrodes immediately, but occasionally would dawdle for up to 70 seconds.

4) At $4 \mathrm{cc} / \mathrm{min}$ water flow ( $0.18 \mathrm{in} / \mathrm{sec})$ and oriented with the electrodes top and bottom, a single bubble could hang up in the electrodes indefinitely.

5) Occasionally, increasing the flow to $6 \mathrm{cc} / \mathrm{min}$ would clear the bubbles.

6) In all conditions and orientations, a water flow of $8 \mathrm{cc} / \mathrm{min}(0.37 \mathrm{in} / \mathrm{sec})$ would clear all bubbles yielding immediate return to the "all water" voltage output.

Since the minimal water flow which contains gas is 90 $\mathrm{cc} / \mathrm{min}$ (12 pph), the gas-tolerant conductivity sensor exhibits a 10:1 water flow/velocity margin on clearing gas under all WPA operating conditions in which gas is contained in the water.

Because the function of the product water sensor is simply to detect ionic breakthrough of the Ion Exchange bed, this sensor can meet its function with the predicted offset. Software modifications have been implemented that will allow the sensor to detect bed breakthrough over the potential offset range. However, the design modifications to the conductivity sensor in the Reactor Health Sensor also apply to the product water sensor. If cost and schedule allocations permit, the product water sensor will also be replaced.

\section{CONCLUSION}

The initial design of the WPA conductivity sensor has specific sensitivities to two-phase fluid flow in microgravity. Based on ground and micro-gravity data, gas will occlude in the sensor housing and result in a sensor offset between 0 and $50 \%$. Because of the potential variability in the offset, MSFC and Hamilton concluded the conductivity sensors in the WPA Reactor Health Sensor would be unable to support their design requirement if exposed to free gas. Therefore, Hamilton has worked with the sensor supplier to develop a new 
sensor design that is compatible with two-phase fluid flow in microgravity at the WPA conditions. MSFC and Hamilton have agreed that the product water conductivity sensor can provide sufficient data for verifying water quality with the offset, though replacing this sensor is also recommended. New sensors will be manufactured and installed in the WPA flight hardware prior to use on the International Space Station.

\section{ACKNOWLEDGMENTS}

The author would like to acknowledge Dr. Fred Best and Cable Kurwitz of Texas A\&M University for their exemplary efforts in building and operating the $\mathrm{KC}-135$ test rig and Dr. Kathleen Hurlbert for her technical and programmatic support in planning and conducting the KC-135 test.

\section{REFERENCES}

1.

2. 